\title{
Experimental evaluation of methods for sampling and assaying intertidal epilithic microalgae
}

\author{
John H. MacLulich \\ Zoology Building, School of Biological Sciences, University of Sydney, N.S.W. 2006, Australia
}

\begin{abstract}
In preparation for more detailed studies of epilithic assemblages, an experimental assessment was made of several of the available methods for both obtaining and assaying intertidal microalgae. Samples were obtained from the natural substratum (by chipping, by scraping and by brushing) and from artificial substrata (stone blocks, glass slides and perspex cubes). The density of microalgal cells in each sample was then estimated by a range of methods (counts using light, fluorescent and scanning electron microscopes; and measurements of chlorophyll concentration). Estimates of cell density on the original substratum were compared and the advantages and disadvantages of each combination of methods are discussed. It is concluded that, for reliablity and reproducibility of results and for ease of application to routine sampling, light microscope studies of samples obtained by brushing the rock surface are most suitable.
\end{abstract}

\section{INTRODUCTION}

Intertidal assemblages of microalgae growing on hard rock surfaces have not been studied in great detail, possibly because of the difficulties associated with obtaining and assaying undamaged samples of sufficient homogeneity. In both freshwater and marine situations, workers have used various techniques to obtain samples. These include scraping, brushing or chipping samples from rock surfaces, or exposing artificial settling plates. Several methods have also been used to assay these samples by direct counts (using light and electron microscopes) or by chlorophyll estimations (for review see MacLulich 1983). Also, many of the methods used for sampling and assaying periphyton have been applied to assemblages growing on natural rock surfaces. These methods have been reviewed by Sladekova (1962).

These various methods, however, have never been compared quantitatively, although it is apparent that some are more suited to certain purposes than others. For example, scanning electron microscopy is very useful for the identification of smaller forms but does not lend itself to rapid assaying of large surface areas. Also, brushing the rock surface does not remove endopelic forms, or those that are very firmly attached, whereas scraping does remove these, but in the process destroys all cellular integrity.
A comparative, experimental evaluation was therefore considered to be essential, in order to assess the most suitable combination of methods for studving intertidal, epilithic microflora.

\section{MATERIALS AND METHODS}

Site. The site studied was a protected bay near Cape Banks, south of Sydney, N.S.W., Australia. An area of relatively smooth sandstone was selected in the midtidal region, characterised by small numbers of the gastropods Cellana tramoserica (Sowerby) (5 to $\left.10 \mathrm{~m}^{-2}\right)$, Bembicium nanum (Lamarck) $\left(5 \mathrm{~m}^{-2}\right)$ and Austrocochlea constricta (Lamarck) $\left(5 \mathrm{~m}^{-2}\right)$ and with a growth of microalgae that made the rock surface appear uniform in colour. No encrusting or foliose macroalgae were growing within the study site.

Sampling. In July 1980, 10 sandstone blocks $(1 \times 5$ $\times 10 \mathrm{~cm}$ ) were attached with screws to the rock surface at random positions within the study area. Ten perspex frames, each holding four $25 \times 75 \mathrm{~mm}$ glass slides were also attached to the surface, at random positions. Ten areas each approximately $10 \times 15 \mathrm{~cm}$ were scraped with a paint scraper until clean bare rock was exposed. After $26 \mathrm{~d}$ the artificial settling surfaces were removed and returned to the laboratory. (Other studies [Underwood 1984, MacLulich 1986] have shown that a 
period of only $21 \mathrm{~d}$ is sufficient for regeneration of the microalgal assemblage.) One glass slide (chosen at random) was removed from each of the 10 perspex holders for examination in the laboratory. On the same day, samples were collected in 3 ways from the previously scraped areas of rock:

(1) Rock chips. Ten small portions of the surface rock, approximately $1 \times 1 \times 0.5 \mathrm{~cm}$, were chipped from the substratum. The rock chips were returned to the laboratory, allowed to dry in air and stored in a desiccator over silica gel for at least $24 \mathrm{~h}$.

(2) Brushing the rock surface. Ten $5 \times 5 \mathrm{~cm}$ areas of the rock surface were outlined, moistened with seawater and scrubbed with a toothbrush. The slurry which accumulated on the toothbrush was washed into a specimen tube containing 10 to $15 \mathrm{ml}$ of sterile filtered seawater. This pattern of brushing was repeated 5 times for each area of rock, by which time the contents of the specimen tube were brown and opaque. This procedure could not be used when the rock surface was awash, either with seawater or rainwater: all samples were taken at the time of low tide, during fine weather. If the samples were not to be studied immediately, approximately $1 \mathrm{ml}$ ( 10 drops) of $37 \%$ formaldehyde (the most common preservative used by other workers, e.g. Nicotri 1977) was then added and the specimen tube was stoppered and shaken. Fresh samples, to be studied immediately, were chilled until returned to the laboratory.

(3) Scraping the rock surface. Ten scrapings were taken by the method described by Underwood (1984) (see also Underwood \& Creese 1976, MacKay \& Underwood 1977). Metal paint scrapers were used to scrape the surface of the rock to a depth at which no further discolouration due to algal growth could be discerned. The rock slurry was quickly transferred to a metal, light-proof tube, approximately $10 \mathrm{ml}$ of $90 \%$ acetone and a pinch of $\mathrm{MgCO}_{3}$ were added and the tube was capped and stored on ice. The area of rock that had been scraped was determined from tracings (Underwood 1984).

Assaying. Ten replicates of samples obtained in each of 5 different ways were available: (1) sandstone blocks; (2) glass slides; (3) rock chips; (4) 'toothbrushings' and (5) scrapings. Each was then assayed by each of the following methods:

(1) Light microscopy. Observations of hard, opaque surfaces (rock chips and sandstone blocks) were made with a Zeiss binocular dissecting microscope at $80 \times$ and with a Leitz Dialux compound microscope with epi-illumination at $100 \times$. Higher magnifications could not be used because of the uneven surfaces being examined and the shallow depth of field at such magnifications. Observations of cells on glass slides were made with a Zeiss compound binocular microscope at
$400 \times$ with phase contrast illumination. It was impossible to observe cells in samples obtained by scraping the rock surfaces: cells were destroyed by the procedure and could not be distinguished from inorganic rubble. Samples obtained by toothbrushing were examined in the following way: the specimen tube was thoroughly shaken and a subsample of approximately $0.5 \mathrm{ml}$ was removed with a Pasteur pipette, placed on a Fuchs-Rosenthal haemocytometer slide and then examined at $400 \times$ with a Zeiss compound microscope using phase contrast illumination. Fifteen quadrats, $0.25 \times 0.25 \times 0.20 \mathrm{~mm}$ deep $\left(1.25 \times 10^{-5} \mathrm{ml}\right)$, were closely examined in each of 2 randomly chosen regions of the slide and the number of all taxa of algal cells was recorded. Two such subsamples from each specimen tube were sampled. This resulted in the sampling of 60 quadrats (that is $7.5 \times 10^{-4} \mathrm{ml}$ ) from each $25 \mathrm{~cm}^{2}$ area: the number of cells counted in such an examination was never less than 400 , usually from 500 to 2000 cells. The average number of cells on each $\mathrm{cm}^{2}$ of rock surface area that had been brushed was then calculated.

(2) Fluorescent light microscopy. A similar procedure to that outlined above was used for observing the fluorescence of chlorophyll in living algal cells in each sample. Samples obtained by scraping and immersion in acetone could not be studied in this way because cellular structure and chlorophyll activity were destroyed. Hard, opaque surfaces were studied at $100 \times$ with a Leitz Dialux compound microscope with epiillumination through an ultra-violet filter, viewed through a $530 \mathrm{~nm}$ barrier filter. Cells growing on glass slides and cells from toothbrushings (mounted on slides) were examined using the same microscope at $400 \times$, adapted for transmitted illumination through an ultra-violet filter. Where necessary, the area of a field of view was calculated and, in every sample, 15 randomly chosen fields of view in each of 2 regions of the sample slide were examined. The density of cells on the original substratum was then calculated.

(3) Scanning electron microscopy. For examination in a S.E.M., samples were prepared in 1 of 2 different ways. Hard surfaces (rock chips, sandstone blocks and glass slides) were air dried and then stored in a desiccator over silica gel for a minimum of $24 \mathrm{~h}$. These samples were cut to an appropriate size, glued to a stub, sputter-coated with gold and examined in a Jeol JSM 35C Scanning Electron Microscope. Samples obtained by toothbrushing were mixed and a $0.5 \mathrm{ml}$ subsample was removed. This subsample was applied drop by drop onto a Gelman GN-6 filter disc, placed on a sheet of Whatman No. 4 filter paper to enhance absorption. An obvious 'spot' was thus formed. The filter disc was allowed to dry in air and then was stored in a desiccator over silica gel for $24 \mathrm{~h}$. When dry, a 
$1 \times 1 \mathrm{~cm}$ square of the filter disc, including the 'spot', was cut out, glued to a stub, sputter-coated with gold and examined in the S.E.M. The area of a field of view, at a nominal magnification of $400 \times$, was established by examination of a marked section of filter paper and by the internal calibration of the instrument. For every sample, 10 randomly chosen fields of view in each of 2 regions of the sample were examined. The cells were counted and the density of cells on the original substratum was calculated

(4) Chlorophyll analysis. (a) Toothbrushing samples. After the appropriate subsamples had been removed for observation in the light microscope, the fluorescent light microscope and the scanning electron microscope, the remaining sample was transferred to a lighttight metal tube and centrifuged for $5 \mathrm{~min}$ at $1200 \mathrm{~g}$. The supernatant was discarded and approximately $1 \mathrm{ml}$ of $90 \%$ acetone and a pinch of $\mathrm{MgCO}_{3}$ were added. The resulting slurry was ground in the tube with a specially designed motorised pestle (Underwood 1984). Approximately $4 \mathrm{ml}$ of $90 \%$ acetone was added and the tube and contents were centrifuged for a further $5 \mathrm{~min}$. The supernatant was poured into a $10 \mathrm{ml}$ measuring cylinder, its volume measured and a subsample was transferred to a quartz glass cuvette. The absorption of the sample at 630,647 and $664 \mathrm{~nm}$ was measured using a Pye Unicam SP6-300 spectrophotometer and the concentration of total chlorophyll in the sample was calculated using the formulae of Jeffrey \& Humphrey (1975). The amount of chlorophyll on the original substratum was thein calcuided.

(b) Scraped samples. These samples could not be assayed in any way other than by chlorophyll analysis because of the inherent destruction of cellular integrity. The chilled samples were returned to the laboratory, ground and centrifuged and the chlorophyll concentration in the supernatant was measured. The amount of chlorophyll per unit area of rock was then calculated.

(c) Sandstone blocks. After portions of each block were removed for observation in the light microscope, the fluorescent light microscope and the scanning electron microscope, the remaining surface of the block was clamped in a vice and scraped in exactly the same manner as were rock surfaces in situ. The area of the block that had been scraped was measured and the sample of scraped rock was treated in precisely the manner as that described for scraped samples obtained from the natural substratum (see above). The amount of chlorophyll per unit area of sandstone block was then calculated.

(d) Glass slides. When the glass slides were returned to the laboratory, they were cut in half. One half-slide was examined with the light microscope and with the fluorescent light microscope and then dried and examined in the scanning electron microscope. The algal scum on the other half-slide was removed with a razor blade and placed in a chilled light-tight metal tube with acetone and $\mathrm{MgCO}_{3}$. The sample was ground and centrifuged and the chlorophyll concentration was measured. The amount of chlorophyll per unit area of glass slide was then calculated.

Perspex cubes. During January 1982, a perspex surface was assessed for suitability for routine sampling and compared with the technique of toothbrushing, which was then being used in several experimental studies of intertidal microalgae (MacLulich 1983, MacLulich unpubl.).

A perspex settling plate was designed so that small portions of the surface could be easily removed and treated for examination in the scanning electron microscope. One hundred perspex cubes, each $16 \times 16 \times$ $16 \mathrm{~mm}$, were attached to a wooden frame with contact cement so as to present a surface $16 \mathrm{~cm}$ square. The upper surface of each cube was roughened with emery paper to encourage settlement or attachment of microalgae. The wooden frame was attached with screws to the rock at the same site at Cape Banks at which the earlier experiment was done. Ten areas of the rock, each approximately $10 \times 10 \mathrm{~cm}$, were scraped clean with a metal paint scraper. After $23 \mathrm{~d}$, the frame was removed and returned to the laboratory and 10 samples were obtained by toothbrushing the areas that had previously been scraped. These 'toothbrush' samples were treated in exactly the same way as those that were obtained in July 1980 (see above). Estimates of the density of cells (by S.E.M., light and fluorescent light microscopy) and of the concentration of chlorophyll on the natural rock surface were obtained.

Thirty perspex cubes were removed from random positions in the wooden frame. Ten cubes were examined with the light microscope and with the fluorescent light microscope in the manner detailed above. Ten cubes were dried, coated with gold or platinum and examined with the S.E.M. in the way outlined above. The algal scum on the remaining 10 cubes was treated in the same way as that removed from glass slides. Estimates of the density of cells and of the chlorophyll concentration on the perspex surfaces were obtained.

\section{RESULTS}

For each combination of method of sampling and method of assaying, 10 estimates of the population of microalgae were obtained. The means and standard deviations of these estimates are given in Tables $1 \& 2$. It proved to be impossible or very difficult to obtain estimates from some combinations of techniques. The reasons for this have already been mentioned. 
Table 1. Estimates of microalgal populations made by different procedures, from samples obtained by a range of methods (Jan 1980). Numbers given are mean (standard deviation) of 10 replicate samples

\begin{tabular}{|c|c|c|c|c|c|}
\hline \multirow[t]{3}{*}{ Techniques for assaying samples } & \multicolumn{5}{|c|}{ Method of obtaining samples } \\
\hline & \multicolumn{3}{|c|}{ Natural substrata } & \multicolumn{2}{|c|}{ Artificial substrata } \\
\hline & Rockchip & Toothbrush & Scraping & Stone & Glass \\
\hline Light microscopy (cells $\mathrm{cm}^{-2} \times 10^{-5}$ ) & $\cdot$ & $\begin{array}{c}1.80 \\
(0.33)\end{array}$ & $\cdots$ & $\cdot$ & $\begin{array}{c}1.04 \\
(0.26)\end{array}$ \\
\hline Fluorescent microscopy (cells $\mathrm{cm}^{-2} \times 10^{-5}$ ) & $\begin{array}{c}0.77 \\
(0.37)\end{array}$ & $\begin{array}{c}0.98 \\
(0.47)\end{array}$ & $\cdots$ & $\begin{array}{c}0.70 \\
(0.49)\end{array}$ & $\begin{array}{c}0.53 \\
(0.21)\end{array}$ \\
\hline Scanning electron microscopy (cells $\mathrm{cm}^{-2} \times 10^{-5}$ ) & $\begin{array}{c}1.48 \\
(0.27)\end{array}$ & $\begin{array}{c}0.91 \\
(0.39)\end{array}$ & $\cdots$ & $\begin{array}{c}1.03 \\
(0.34)\end{array}$ & $\begin{array}{c}1.21 \\
(0.30)\end{array}$ \\
\hline Chlorophyll analysis $\left(\mu \mathrm{g} \mathrm{g}^{-1} \mathrm{~cm}^{-2}\right)$ & $\begin{array}{c}3.21 \\
(0.64)\end{array}$ & $\begin{array}{c}1.09 \\
(0.85)\end{array}$ & $\begin{array}{c}3.93 \\
(0.75)\end{array}$ & $\begin{array}{c}0.76 \\
(0.35)\end{array}$ & $\begin{array}{c}0.16 \\
(0.37)\end{array}$ \\
\hline
\end{tabular}

If it is assumed that chlorophyll analysis of scrapings of rock measures the total chlorophyll level on and in the rock, and hence closely estimates the total population of algal cells, then it can be seen that samples obtained by toothbrushing remove only some $28 \%$ of this total population (see Table 1). This result was further substantiated by more detailed experimental studies designed to assess the effectiveness of toothbrushing (MacLulich 1983). By the same criteria, the growth of microalgae on artificial substrata seems to be considerably less than that on natural substrata (ranging from $4 \%$ for glass slides to $19 \%$ for sandstone blocks; see Table 1).

Counts of algal cells using a light microscope, where feasible, were greater than counts obtained using a fluorescent light microscope. Counts of algal cells on hard substrata using the S.E.M. were greater than counts made using the fluorescent light microscope. Counts of cells in 'toothbrush' samples using the

Table 2. Estimates of microalgal populations made by different procedures, from samples obtained by toothbrushing and from perspex cubes (Jan 1982). Numbers given are the mean (standard deviation) of 10 replicate samples

\begin{tabular}{|ccc|}
\hline $\begin{array}{c}\text { Techniques for } \\
\text { assaying samples }\end{array}$ & $\begin{array}{c}\text { Method of obtaining samples } \\
\text { Toothbrushing }\end{array}$ & $\begin{array}{c}\text { Perspex } \\
\text { cubes }\end{array}$ \\
\hline $\begin{array}{c}\text { Light microscopy } \\
\left.\text { (cells cm }{ }^{-2} \times 10^{-5}\right)\end{array}$ & $2.02(0.41)$ & $1.68(0.49)$ \\
$\begin{array}{c}\text { Fluorescent microscopy } \\
\left(\text { cells cm } \mathrm{cm}^{-2} \times 10^{-5}\right)\end{array}$ & $1.31(0.66)$ & $0.67(0.41)$ \\
$\begin{array}{c}\text { Scanning electron micros- } \\
\left.\text { copy (cells cm } \text { cm }^{-2} \times 10^{-5}\right)\end{array}$ & $0.84(0.26)$ & $0.85(0.40)$ \\
$\begin{array}{c}\text { Chlorophyll analysis } \\
\left(\mu \mathrm{g} \mathrm{g}^{-1} \mathrm{~cm}^{-2}\right)\end{array}$ & $1.47(0.72)$ & $0.21(0.41)$ \\
\hline
\end{tabular}

S.E.M. were less than counts of the same samples using the light microscope.

The counts of cells growing on perspex cubes showed a similar trend to the counts obtained from 'toothbrush' samples: when using a light microscope the counts were greatest. Chlorophyll analysis of the scum from perspex cubes revealed that the density of growth of microalgae on perspex is very similar to that on glass slides.

A consideration of the standard deviations (SDs) of the means of the values given in Tables $1 \& 2$ would suggest a difference in the reliability of counts obtained by different assays. Chlorophyll analyses provided proportionally much higher SDs than other methods, while light microscope and S.E.M. assays gave the lowest SDs, and hence the more consistent results.

\section{DISCUSSION}

Some techniques were, qualitatively, more suitable for routine sampling than others. Light microscope studies were best made using glass slides - either of samples collected by toothbrushing or of samples grown on slides in the field. These samples could be examined with little difficulty, at useful magnifications up to $1000 \times$. This method has been used by many workers, with apparent ease (Aleem 1949, 1950, Calow 1973, Nicotri 1977. Underwood 1984). The use of the compound light microscope to examine cells growing on opaque surfaces (rock or perspex) was limited by the shallow depth of field in the useful magnification range $(200 \times$ to $400 \times)$. The uneven topography of the surface necessitated constant changes of focus which, if the surface were extremely rough, could result in accidental damage of the objective lens (even when 
using long working-distance lenses). Also, surface illumination was often insufficient to distinguish cellular material from the underlying substratum. Binocular dissecting microscopes were limited by the maximum obtainable magnification, usually only $100 \times$, which was too low to identify and count all but the largest of algal cells. Kennelly (1983), however, has used such microscopes to observe the development of macroalgal sporelings.

Fluorescent light microscope studies were also best made of samples on glass slides. The study of opaque surfaces was somewhat easier when epi-fluorescent illumination was employed because living algal cells (containing chlorophyll) were usually very easily distinguished. Jones (1974) successfully used this method to study freshwater diatoms on rocks and pebbles. Differences in the intensity and colour of fluorescence were observed. These were probably related to the different concentrations of chlorophylls $a, b$ and $c$ which fluoresce at different wavelengths that characterize different types of algae. Two drawbacks of this technique became apparent. First, the fluorescence was only observed on samples that were freshly collected, that is, when algal cells were still alive and heaithy. One or $2 \mathrm{~h}$ of transportation and storage resulted in a decrease in the intensity of fluorescence to a barely detectable level. Second, even with fresh, living samples, the fluorescence was observed to decay after even only short exposure to ultra-violet light. After 2 min of observation (usually sufficient for counting all cells in a field of view) the intensity of fluorescence was virtually zero.

Samples that were studied in the S.E.M. required a substantial amount of preparation. The major drawback of using the S.E.M. was that the dehydration process and the necessary subjection of the sample to high vacuum was observed to lead to distortion of all but the hardest-structured cells (diatoms). The technique has been used successfully by Nicotri (1977) and others, and it is noteworthy that the S.E.M. has become a routine tool of diatom taxonomists (Round 1971, Hasle 1977).

Of the methods tried for obtaining samples of microalgae, some were found to require more effort than others. Removal of rock chips with a hammer and chisel was found to be fast and easy, and had the advantage that samples could be stored almost indefinitely. This was, however, a very destructive method of sampling, in that the same area could not be resampled. Scraping the rock surface was only slightly more arduous and time consuming but necessitated that samples be speedily returned to the laboratory and assayed before the chlorophyll degraded. This was also a destructive method of sampling. Brushing the rock surface with a toothbrush was a reasonably simple process, requiring little equipment and being quite rapid (in the time of a single low tide [4 h] 120 samples could be obtained). This method was much less destructive than those mentioned above and samples obtained in this way could be stored indefinitely.

The use of artificial substrata (sandstone, glass and perspex), while providing samples that can be easily assayed in the laboratory, required a considerable amount of preparation, design, construction and installation (involving drills, generators and other equipment). Also, such man-made structures on coastal rock platforms tended to suffer from vandalism. It was found that salt crystallization was more manifest on perspex cubes than on rock chips. This was probably related to the non-porous nature of the perspex cubes, which did not allow drainage of seawater. The use of sandstone cubes could avoid this problem.

It was concluded, based on both qualitative and quantitative aspects of the results obtained, that the most suitable methods for routine sampling were: (1) Light microscope studies of samples obtained by toothbrushing. Such samples were quick and easy to obtain and the counts yielded consistent, comparative results. (2) S.E.M. studies of rock chips. Such samples were also quick and easy to obtain but, of course, the same area could not be resampled. The samples required careful preparation but the counts yielded consistent results. This method was the most useful for identification of diatoms, a major component of the microalgal assemblage. These methods have been used, successfully, to investigate spatial and temporal changes in populations of intertidal microflora (MacLulich unpubl.) and the initial colonization of bare rock by microflora (MacLulich 1986).

Acknowledgements. I thank the staff of the Electron Microscope Unit at the University of Sydney for their assistance in the use of the S.E.M. Drs. A. Underwood and P. Jernakoff provided constructive advice and helpful comments during this study and $S$. Kennelly suggested several alterations to the manuscript. The research described here formed part of the requirements of the degree of M.Sc. in the Department of Zoology, University of Sydney.

\section{LITERATURE CITED}

Aleem, A. A. (1949). Distribution and ecology of marine littoral diatoms. Bot. not. 102: 414-440

Aleem, A. A. (1950). Distribution and ecology of British marine littoral diatoms. J. Ecol. 38: 75-106

Calow, P. (1973). The food of Ancylus fluviatilis (Mull.), a littoral stone dwelling herbivore. Oecologia (Berl.) 13: 113-133

Hasle, G. R. (1977). Use of electron microscopy in morphological and taxonomical diatom studies. In: Werner, D. (ed.) The biology of diatoms (Botanical Monographs Vol. 13). Blackwell Scientific Publications, Oxford, p. 18-23 
Jeffrey, S. W., Humphrey, G. F. (1975). New spectrophotometric equations for determining chlorophylls $a, b, c 1$ and $c 2$ in higher plants, algae and natural phytoplankton. Biochem. Physiol. Pflanzen 167: 191-194

Jones, J. G. (1974). A method for observation and enumeration of epilithic algae directly on the surface of stones. Oecologia (Berl.) 16: 1-8

Kennelly, S. J. (1983). An experimental approach to the study of factors affecting algal colonization in a sublittoral kelp forest. J. exp. mar. Biol. Ecol. 68: 257-276

Mackay, D. A., Underwood, A. J. (1977). Experimental studies on homing in the intertidal patellid limpet Cellana tramoserica (Sowerby). Oecologia (Berl.) 30: 215-238

MacLulich, J. H. (1983). Aspects of the ecology of intertidal epilithic microflora at Green Point, New South Wales. M.Sc. thesis, Univ. of Sydney

MacLulich, J. H. (1986). Colonization of bare rock surfaces by microflora in a rocky intertidal habitat. Mar. Ecol. Prog. Ser. 32: 91-96

Nicotri, M. E. (1977). Grazing effects of four marine intertidal herbivores on the microflora. Ecology 58: 1020-1032

Round, F. E. (1971). Benthic marine diatoms. Oceanogr mar. Biol. A. Rev. 9: 83-139

Sladekova, A. (1962). Limnological investigation methods for the periphyton ('Aufwuchs') community. Bot. Rev. 28: 286-350

Underwood, A. J. (1984). The vertical distribution and seasonal abundance of microalgae on a rocky shore in $\mathrm{New}$ South Wales. J. exp. mar. Biol. Ecol. 78: 199-220

Underwood A. J., Creese, R. G. (1976). Observations on the biology of the trochid gastropod Austrocochlea constricta (Lamarck) (Prosobranchia). II. The effects of available food on shell banding pattern. J. exp. mar. Biol. Ecol. 23: $229-240$

This article was presented by Professor J. S. Pearse; it was accepted for printing on September 29, 1986 